\title{
PENGARUH MODEL PEMBELAJARAN FLIPPED CLASSROOM TIPE TRADITIONAL FLIPPED BERBANTUAN VIDEO TERHADAP KEMAMPUAN BERPIKIR KREATIF SISWA PADA MATERI BANGUN RUANG SISI DATAR
}

\author{
Anis Umi Khoirotunnisa ${ }^{\text {1) }}$, Boedy Irhadtanto ${ }^{2)^{*}}$ \\ ${ }^{1}$ Fakultas Pendidikan Matematika dan IPA, IKIP PGRI Bojonegoro \\ email: Anis.umi@ikippgribojonegoro.ac.id \\ ${ }^{2}$ Fakultas Pendidikan Ilmu Pengetahuan Sosial, IKIP PGRI Bojonegoro \\ email: Boedy.irh@ikippgribojonegoro.ac.id
}

\begin{abstract}
The purpose of this study was to determine the effect of students' creative thinking abilities using traditional flipped classroom learning models using video-assisted and conventional learning on flat side space. The population in this study were all eighth grade students of MTs Abu Dzarrin. The Samples were taken by cluster random sampling technique. The selected sample is class VIII A as the experimental class and class VIII C as the control class. The instrument used in this study was students' creative thinking abilities instrument in the form of a essay question. The Analysis of the test instrument using the validity test and reliability test. Prerequisite Test analysis uses the normality test and homogeneity test while testing the hypothesis with the t-independence simple test using SPSS 22 for Windows. The average difference test results with the t-test obtained sig 1-tailed by 0,000 with a significance level of 5\%. The value of sig $<0.05$ so that it can be concluded that the creative thinking ability of students is better to use the model of traditional flipped classroom learning assisted video assisted compared to conventional learning
\end{abstract}

Keyword: Flipped Classroom, traditional flipped, creative thinking abilities.

Abstrak: Tujuan dari penelitian ini untuk mengetahui pengaruh kemampuan berpikir kreatif siswa dengan menggunakan model pembelajaran flipped classroom tipe traditional flipped berbantuan video dan pembelajaran konvensional pada materi bangun ruang sisi datar. Populasi dalam penelitian ini adalah seluruh siswa kelas VIII MTs Abu Dzarrin. Sampel diambil dengan teknik cluster random sampling. Sampel terpilih yaitu kelas VIII A sebagai kelas eksperimen dan kelas VIII C sebagai kelas kontrol. Instrumen yang digunakan dalam penelitian ini adalah Instrumen kemampuan berpikir kreatif siswa yang berupa soal uraian. Analisis instrumen test menggunakan uji validitas dan uji reliabilitas. Uji Prasarat analisis menggunakan Uji normalitas dan Uji Homogenitas sementara pengujinan hipotesis dengan uji$t$ independence simple test Menggunakan SPSS 22 for Windows. Hasil uji beda rata-rata dengan uji-t diperoleh sig 1-tailed sebesar 0,000 dengan taraf signifikansi 5\%. Nilai sig <0,05 sehingga dapat disimpulkan bahwa kemampuan berpikir kreatif siswa lebih baik menggunakan model pembelajaran flipped classroom tipe traditional flipped berbantuan video dibandingkan dengan pembelajaran konvensional.

Kata kunci: Flipped Classroom, traditional flipped, kemampuan berpikir kreatif.

\section{PENDAHULUAN}

Permendiknas RI No. 41 tahun 2007 tentang standar proses menyatakan bahwa dalam penyelenggaraan pendidikan diperlukan guru yang mengembangkan potensi dan kreativitas peserta didik.
Sedangkan dalam permendikbud no. 65 tahun 2013 menyatakan bahwa karakteristik pembelajaran pada setiap satuan pendidikan terkait erat pada standar isi. Standar isi memberikan kerangka konseptual tentang kegiatan belajar dan pembelajaran yang 
diturunkan dari tingkat kompetensi dan ruang lingkup materi. Peningkatan kualitas guru harus dilakasanakan dengan serius, salah satunya dengan penerapan model pembelajaran di kelas sebagai penyokong proses pembelajaran.

Pada beberapa studi tentang efektifitas pembelajaran telah banyak dikembangkan model-model pembelajaran. Salah satunya adalah Flipped Classroom, yakni model pembelajaran terbalik atau membalik kelas yang diterapkan guru pada siswa. Model pembelajaran flipped classroom membongkar kelas-kelas tradisional yang pada umumnya telah menjadi rutinitas guru yakni memberikan materi di kelas kemudian memberikan tugas untuk dikerjakan di kelas dan di luar kelas. (Adhitiya, et al. 2015) menyatakan bahwa siswa dalam kelas terbalik menjadi lebih sadar proses belajar mereka sendiri daripada siswa dalam pembelajaran yang tradisional. Dengan demikian, siswa di kelas terbalik perlu memiliki lebih banyak ruang untuk merefleksikan kegiatan belajar mereka sehingga mereka dapat membuat hubungan isi materi pelajaran.

Kreativitas merupakan kemampuan seseorang dalam mengolah ide yang ada, menggabungkan antara ide dan konsep yang mungkin didapatkanya dari proses belajar ataupun pengalaman belajar sebelumnya kemudian mengolahnya menjadi informasi baru. Menurut supriyadi definisi kreatif adalah kemampuan seseorang untuk menciptakan sesuatu yang baru, baik berupa gagasan atau karya nyata yang relative berbeda dari yang telah ada. Kreativitas merupakan kemampuan berpikir tingkat tinggi yang mengimplikasikan terjadinya eskalasi dalam kemampuan berpikir, ditandai oleh suksesi, diskontinuitas, diferensiasi, dan integrase antara tahap perkembangan. Manusia yang kreatif selalu berusaha untuk memberi makna pad proses belajarnya. Salah satu hal yang mendorong manusia untuk belajar adalah adanya sifat kreatif dalam dirinya dan keinginan untuk maju. Ia tidak pernah takut pada kesalahan dan kegagalan akan mendorongnya pada pencapaian prestasi yang memuaskan.

Berpikir kreatif membutuhkan ketekunan, disiplin diri, dan perhatian penuh, meliputi aktivitas mental seperti: 1) mengajukan pertanyaan; 2) mempertimbangkan informasi baru dan ide yang tidak lazim dengan pikiran terbuka; 3) membangun keterkaitan, khususnya diantara hal-hal berbeda; 4) menghubungkan berbagai hal dengan bebas. Menurut utami munandar dalam (Panjaitan \& Surya, 2017) menerangkan bahwa kreativitas adalah proses kemampuan yang mencerminkan kelancaran, keluwesan, dan orisinalitas dalam berpikir, serta kemampuan untuk mengelaborasi suatu gagasan. Berpikir kreatif sebagai kemampuan umum untuk menciptakan sesuatu yang baru, sebagai kemampuan untuk memberikan gagasan baru yang dapat diterapkan dalam pemecahan masalah atau sebagai kemampuan untuk melihat hubungan-hubungan baru antara unsurunsur yang ada sebelumnya. Menurut Krulik dalam (Saputra, 2017) berpikir kreatif adalah pemikiran yang original dan menghasilkan suatu hasil yang kompleks, yang meliputi merumuskan ide-ide, menghasilkan ide-ide baru dan menentukan keefektifanya.

Pada pembelajaran flipped classroom siswa menonton video pembelajaran dirumah untuk menemukan sendiri konsep materi pelajaran sesuai dengan kecepatan masing-masing. Pada saat di kelas siswa lebih siap dalam menerima pelajaran. Materi pelajaran telah dipelajari dirumah melalui media video sehingga siswa memiliki waktu lebih di kelas untuk mengerjakan tugas, latihan soal, ataupun diskusi terkait materi yang telah 
disampaikan guru lewat video sebelumnya. Siswa dalam kelas terbalik menjadi lebih sadar proses belajar mereka sendiri daripada siswa dalam pembelajaran yang tradisional (Frederikson dalam (Rindaningsih, 2018). Pembelajaran seperti ini memungkinkan siswa belajar mandiri dan lebih siap pada pertemuan selanjutnya. Dari uraian diatas, peneliti lebih jauh ingin mengetahui apakah terdapat pengaruh model pembelajaran Flipped Classroom tipe Traditional Flipped Berbantuan video terhadap Kemampuan Berpikir Kreatif siswa pada materi Bangun Ruang Sisi datar.

\section{METODE PENELITIAN}

Penelitan ini dilakukan di MTs Abu Dzarrin yang berada di desa sumber tlaseh kecamatan dander kabupaten bojonegoro. Populasi pada penelitian ini adalah seluruh siswa kelas VIII MTs, Abu Dzarrin. Tahun Ajaran 2018/2019. Metode yang digunakan dalam penelitian ini adalah metode penelitian eksperimen. Desain dalam penelitian eksperimen ini yaitu pretest-post test group design. Teknik Pengambilan sampel menggunakan teknik cluster random sampling dimana keseluruh populasi dibagi dalam kelas-kelas kemudian memilih secara acak. Berdasarkan teknik tersebut terpilih kelas VIII A sebagai kelas eksperimen dan kelas VIII C sebagai kelas control. Pretest dilakukan untuk mengetahui kemampuan awal siswa terkait penelitian yang dilakukan yakni tentang kemampuan berpikir kreatif. Selanjutnya adalah dengan memberikan treatment pada kelas eksperimen dengan meggunakan model pembelajaran flipped classroom tipe traditional flipped berbantuan video, sementara untuk kelas control menggunakan model pembelajaran konvensional. Setelah pembelajaran selesai selanjutnya akan dilakukan post-test. Posttes dilakukan pada kedua kelas baik eksperimen maupun control untuk mengetahui kemampuan akhir siswa setelah perlakuan. Instrumen dalam penelitian ini yaitu instrument tes. Instrumen tes berupa soal untuk mengetahui kemampuan berpikir kreatif siswa. Pada instrument tes terdapat 10 soal yang disesuaikan dengan indikator kemampuan berpikir kreatif, diantaranya kelancaran, keluwesan, orisinalitas dan elaborasi. Soal tersebut dianalisis menggunakan bantuan software SPSS 22 for windows. Analisis Instrumen tes tersebut meliputi uji validitas dan reliabilitas. Pengujian lainya adalah uji normalitas, uji homogenitas,dan pengujian hipotesis dengan uji rerata.

\section{HASIL DAN PEMBAHASAN}

Hasil rata-rata pretest kemampuan berpikir kreatif pada kelas eksperimen adalah 50,75 setelah pretest dilaksanakan pembelajaran dengan menggunakan model pembelajaran flipped classroom tipe traditional flipped berbantuan video selama 4 pertemuan tatap muka dan beberapa video pembelajaran yang dapat dapat dijadikan media belajar sendiri dirumah. Selanjutnya dilaksanakan post test dengan perolehan nilai rata-rata sebesar 85,6. Selisih yang diperoleh adalah sebesar 34,85. Berdasarkan hasil posttest dapat diketahui apakah terdapat peningkatan kemampuan berpikir kreatif siswa pada materi bangun ruang sisi datar secara signifikan atau tidak pada kelas eksperimen. Data yang diperoleh diolah dengan menggunakan bantuan software SPSS 22 for windows. Berdasarkan hasil uji normalitas menggunakan uji Kolmogorov smirnov diperoleh data pretest dengan $p$-value $>0.05$ artinya Ho diterima maka data tersebut berasal dari populasi yang berdistribusi normal. Dan untuk data post tes dengan pvalue > 0,05 artinya Ho juga diterima sampel berasal dari populasi yang berdistribusi normal. 
Tabel 1. Hasil uji normalitas pretest

Ore-Sarnple Kolmogoron-Smirnow Test

\begin{tabular}{|ll|r|}
\hline & & \multicolumn{1}{|c|}{$\begin{array}{c}\text { Nrstandardiz } \\
\text { edResidual }\end{array}$} \\
\hline Normal Parametersa.b & Mear & 32 \\
Most Extreme Difrerences & Std. Deviation & 2.09853410 \\
& Absolute & .194 \\
& Positive & .194 \\
Test Statistic & Negative & -.135 \\
Asymp. Sig. (2-tailed) & & .194 \\
\hline
\end{tabular}

a. Test distribution is Normal.

b. Calculated from data.

c. Lilliefors Significance Correction.

Tabel 2. Hasil uji normalitas posttest

\begin{tabular}{|c|c|c|}
\hline & & $\begin{array}{l}\text { Unstandardiz } \\
\text { ed Residual }\end{array}$ \\
\hline $\mathrm{N}$ & & 32 \\
\hline \multirow{2}{*}{ Normal Parameters } & Mean & םםםםםםם. \\
\hline & Std. Deviation & 9.28951966 \\
\hline \multirow[t]{3}{*}{ Most Extreme Differences } & Absolute & .150 \\
\hline & Positive & .150 \\
\hline & Negative & -.117 \\
\hline Test Statistic & & .150 \\
\hline Asyrnp. Sig. $\{2$-tailed\} & & $064^{c}$ \\
\hline
\end{tabular}

a. Test distribution is Normal.

b. Calculated from data.

c. Lilliefors Significance Correction.

Uji prasarat analisis selanjutnya adalah uji homogenitas kemampuan berpikir kreatif siswa pada kelas eksperimen dan kelas control. Hasilnya adalah sebagai berikut.

Tabel 3. Hasil uji homogenitas Pretest

Pretest

\begin{tabular}{cccc}
\hline Levene Statistic & df1 & df2 & Sig. \\
\hline 1.975 & 1 & 62 & .165 \\
\hline
\end{tabular}

Tabel 4. Hasil uji homogenitas Posttest

Postest

\begin{tabular}{cccc}
\hline Levene Statistic & df1 & df2 & Sig. \\
\hline .154 & 1 & 62 & .696 \\
\hline
\end{tabular}

Berdasarkan table output "test of homogenieity of variance diatas diketahui nilai signifikansi (sig) variable hasil pretest dan posttes pada siswa kelas eksperimen dan control adalah sebesar $0,165>0,05$ maka dapat disimpulkan bahwa varians data pretest dan postes kemampuan berpikir kreatif siswa kelas eksperimen dan control adalah sama atau homogen 
Tabel 5. Hasil uji-t kelas eksperimen dan kontol terhadap kemampuan berpikir kreatif.

\begin{tabular}{|ll|r|r|r|r|}
\multicolumn{8}{|c|}{ Group Statistics } \\
\hline \multicolumn{1}{|c|}{ kelas } & N & Mean & Std. Deviation & $\begin{array}{c}\text { Std. Error } \\
\text { Mean }\end{array}$ \\
\hline Berpikir Kreatif & Eksperimen & 32 & 85.6250 & 8.85274 & 1.56496 \\
& Kontrol & 32 & 70.0000 & 3.30140 & 1.64427 \\
\hline
\end{tabular}

\begin{tabular}{|c|c|c|c|c|c|c|}
\hline & & & \multicolumn{4}{|c|}{ Independent Samples Test } \\
\hline & & \multicolumn{2}{|c|}{$\begin{array}{c}\text { Levene's Test for Equality of } \\
\text { Variances }\end{array}$} & \multirow[b]{2}{*}{ t } & \multirow[b]{2}{*}{ df } & \multirow[b]{2}{*}{ sig. (2-talled) } \\
\hline & & $\mathrm{F}$ & sig. & & & \\
\hline Berpikir Kreatif & $\begin{array}{l}\text { Equal variances } \\
\text { assumed }\end{array}$ & \multirow[t]{2}{*}{.154} & \multirow[t]{2}{*}{.695} & \multirow{2}{*}{$\begin{array}{l}6.883 \\
6.883\end{array}$} & \multirow{2}{*}{$\begin{array}{r}62 \\
61.849\end{array}$} & .000 \\
\hline & $\begin{array}{l}\text { Equal variances not } \\
\text { assumed }\end{array}$ & & & & & .000 \\
\hline
\end{tabular}

Selanjutnya adalah uji Hipotesis menggunakan uji-t. Pengujinan menggunakan SPSS22 for windows untuk mengetahui apakah terdapat pengaruh model pembelajaran Flipped Classroom tipe traditional flipped berbantuan video terhadap kemampuan berpikir kreatif siswa pada materi bangun ruang sisi datar.

Dari hasil uji-t diatas dapat dilihat bahwa nilai sig $<0,005$ sehingga dapat disimpulkan bahwa terdapat pengaruh model pembelajaran Flipped Classroom tipe traditional flipped berbantuan video dan pembelajaran konvensional terhadap kemampuan berpikir kreatif siswa pada materi bangun ruang sisi datar. Jika dilihat rerata dari kedua kelompok dimana rerata untuk kelas eksperimen adalah 85,6 dan rerata kelas control 70 maka dapat disimpulkan bahwa penerapan model flipped classroom berbantuan video lebih baik daripada model konvensional terhadap kemampuan berpikir kreatif siswa.

Hal ini mungkin terjadi karena saat pembelajaran flipped classroom siswa lebih siap menerima pelajaran karena telah belajar mandiri dirumah dengan menggunakan video yang telah dibagikan. Hal ini sesuai dengan penelitian yang disampaikan oleh Herry dan sutama: 2016 dimana hasil penelitianya menyatakan bahwa model pembelajaran flipped classroom dapat meningkatkan motivasi, keaktifan dan keterampilan belajar. Selain itu stephani et all (2015) menyatakan bahwa literatur bidang ilmu pengetahuan membutuhkan model pembelajaran yang melibatkan siswa dalam proses pembelajaran, membangun pengetahuan dan memiliki output baru yang melampaui informasi yang disajikan dikelas.

Penelitian oleh walid Mahmoud sdouh (2013) tentang perbedaan prestasi, keterampilan dan sikap kreatif penggunaan pembelajaran brainstrorming dan computer menunjukkan hasil yang signifikan dan efektif. Hal ini bermakna bahwa model pembelajaran flipped classroom tipe traditional flipped berbantuan video dapat meningkatkan aspek kognitif, afektif dan psikomotor. Guru yang menggunakan model flipped classroom harus berusaha menyuguhkan konten yang menarik dengan berbagai metode dalam video yang disajikan. Siswa juga memiliki keleluasaan dalam belajar juga kemandirian belajar dibandingkan dengan model pembelajaran tradisional.

Pembelajaran yang telah di pelajari sebelumnya memungkinkan siswa memiliki jeda waktu untuk memahami, merumuskan dan merefleksikan hasil belajarnya. Dalam indikator kemampuan berpikir kreatif yakni kelancaran dan keluwesan menuntut siswa untuk berpikir secara terbuka, tidak terpatok pada cara yang penyelesaian soal 
yang diajarkan guru dan dengan model flipped classroom ini siswa bisa merumuskan pertanyaan setelah memahami video yang dilihat. Pertanyaan yang disusun dapat disampaikan dihari berikutnya saat pertemuan dikelas.

\section{SIMPULAN}

Model Flipped Classroom tipe traditional Flipped berbantuan video yang diterapkan pada penelitian ini bertujuan agar siswa dapat belajar dengan santai dan tidak terbatas dikelas. Prinsip pembelajaran terbalik dimana siswa belajar terlebih dahulu baru kemudian hasil belajarnya dibahas dikelas pada hari berikutnya memungkinkan siswa memiliki jeda waktu untuk merumuskan pertanyaan dan memahami materi secara menyeluruh. Hasil penelitian ini menunjukkan nilai $t$ sebesar $0,000<0,005$ lebih kecil dari nilai signifikansi yang artinya pembelajaran flipped classroom tipe traditional flipped dan pembelajaran konvensional berpengaruh terhadap kemampuan berpikir kreatif siswa pada materi bangun ruang sisi datar. Sementara untuk melihat mana yang lebih baik dapat dilihat dari rerata pada masing-masing hasil pengukuran kemampuan kreatif siswa dalam menyelesaikan soal. Dimana pada kelas eksperimen rerata sebesar 85,6 dan rerata kelas control adalah 70 sehingga dapat ditarik kesimpulan bahwa model pembelajaran Flipped Classroom tipe Traditional Flipped berbantuan video lebih baik daripada pembelajaran konvensional terhadap kemampuan berpikir kreatif siswa pada materi bangun ruang sisi datar.

\section{DAFTAR RUJUKAN}

Aditya, E., Prabowo, A., \& Arifudin, R. (2015). Studi Komparasi Model Pembelajaran Traditional Flipped Dengan Peer Instruction Flipped
Terhadap Kemampuan Pemecahan Masalah. Unnes Journal of Mathematics Education, 117-126.

Damayanti, H. N., \& sutama. (2016). Efektivitas flipped classroom terhadap sikap dan keterampilan belajar matematikan di SMK. Jurnal Managemen Pendidikan, 28.

Panjaitan, A. H., \& Surya, E. (2017). Creative Thinking (Berpikir Kreatif) Dalam Pembelajaran Matematika. Researchget.

Rindaningsih, I. (2018). Efektivitas Model Flipped Classroom dalam Mata Kuliah Perencanaan Pembelajaran Prodi S1 PGMI UMSIDA. ICECRS (pp. 51-60). Sidoarjo: Universitas Muhammadiyah Sidoarjo.

Saputra, H. (2017). Kemampuan Berpikir Kreatif Matematis Pada Siswa Sekolah. Researchgate.

Sdouh, W. M. (213). The effect of using The Strategies of Brainstrorming and Computer Education In Academic Achievement and the Development of Creative Thingking Skills of Sixth Grade student in Jordan and Their Attitudes Towards Learning Mathematics. European Scientific Journal, 50-62.

Stephanie Butler Velegol, s. E. (2015). The Evolution of a FLipped Classroom: Evidence-Based recommendation. American Society For engineering Education Pennsylvania, 112-115.

Bennett, B.E., Spencer, D., Bergmann, J., Cockrum, T., Musallam, R., Sams, A., Fisch, K., \& Overmyer, J. (2011). The flipped class manifest. The Daily Riff. Retrieved from: 
http://www.thedailyriff.com/article s/the-flipped-class-manifest-

823.php
Bergmann, J., \& Sams, A. (2012). Flipped Your Classroom: Reach every student in every class every day. USA: ISTE 
24 JURNAL PENDIDIKAN EDUTAMA, Vol 7, No. 2, Juli 2020 